\title{
List of boxes and tables
}

\section{Boxes}

3.1 Membership of Council of Wales and Monmouthshire 50

\section{Tables}

2.1 Scottish Secretaries, 1885-1999

3.1 Division of functions between Whitehall and the Welsh Office (1996)

3.2 Secretaries of State for Wales

4.1 Imperial contributions paid by Northern Ireland and amount that would have been paid on strict population basis

6.1 1979 Scottish devolution referendum

6.21997 Scottish devolution referendum

6.3 Results of Scottish Parliament elections, 1999-2007

7.1 The 1979 and 1997 Welsh devolution referendums

7.2 Results of Welsh Assembly elections, 1999-2007

8.1 Results of the referendums on the Belfast Agreement, May 1998

8.2 Northern Ireland Assembly election results 1998-2007

9.1 Whitehall's 'regional turn' 